\title{
Toward Firm Sustainability through Green Supply Chain Management and Green Marketing in the New Norm
}

\author{
Yuary Farradia \\ \{juaryfarradia@yahoo.com\} \\ Faculty of Economics-Universitas Pakuan, Jalan Pakuan Bogor, Indonesia
}

\begin{abstract}
COVID 19 pandemic generates a high demand on chemical industry which creates more operational activities. Along these activities, it is also a high concern on the climate change within chemical industry subject to a resilient in order to form a sustainable future in particular on economic sustainability to avoid any possibility of another global destructive situation. Sustainability and environmental issues become a primary consideration in Indonesia toward green industry. An involvement of the environment in supply chain management has been developed namely green supply chain management (GSCM). Having 'green' component within the supply-chain management involves relationships among supply-chain management and natural environment. Firms are also need to incorporate the green concept in their marketing mix through green innovation on the product, pricing with green concept, green distribution and green promotion. The concept of green marketing mix (GMM) refer to various effort to achieve the strategic and financial goals of a firm trough reducing any negative impact on the natural environment. This paper demonstrates the influences of GSCM on economic sustainability and explores the relationship between GSCM and GMM practices on economic sustainable firm performance subject to new normal era. The study of 58 chemical firms in Indonesia by using Smart PLS 3, revealed that GSCM has a positive indirect effect through GMM on sustainability economic performance.
\end{abstract}

Keywords: Green Marketing, Green Supply Chain Management, New Norm, Economic Sustainability

\section{Introduction}

Covid-19 pandemic has impact on declining demand to the general chemicals industry (Rais, 2020; Strategy \& pwc, 2020). However, there is a significant light rise in the demand of chemical as the basis for the packaging materials which used to prevent food, personal care, medicine, and medical products from any contamination (Coatingsworld, 2020). Despite COVID-19 continued with lockdowns in a number of countries, the chemical industry adopted ways where they keep continue production to provide antiseptics, disinfectants, protective 
packaging and various basic necessities against the pandemic (Accenture, 2020).

The chemical industry plays an important role for the wealth of a country. There are three groups of chemical industry products namely basic, speciality and consumer chemicals (Lazonby and Waddington, 2020). Basic chemicals which also sold to the others chemical industry are divided into petrochemicals, polymers, basic inorganics and organics. The organic compounds are either building blocks such as propene, ethene, benzene and butadiene and how they are used to make plastics and pharmaceuticals. Speciality chemicals covers a wide variety of chemicals for crop protection, paints, ink colorants, textile, paper and engineering. Consumer chemicals includes, soaps, detergents, other toiletries, surfactants, and synthetic chemicals for toiletries, fragrances and cosmetics

In the new norm era, the governments are likely to invest and regulate "key supply chains" on pharmaceutical and personnel protective equipment (PPE). Hence, the demand of personal protective equipment (PPE) in particular surgical mask is increase as well as for various related pharmaceutical products derived from petrochemical production. Data in April 2020 indicated that the country production monthly capacity was 394.82 million surgical masks, more than double increment prior to the pandemic. As a result, the Ministry of Industry has forecasted a surplus of almost 2 billion surgical mask by the end of the year (The Jakarta Post, 2020). Indeed, the outbreak of pandemic Covid -19 impose the urgency of PPE in term of healthcare as well as hand sanitizer. The main raw materials used in PPE are originate from petrochemicals products. As the result, there is high opportunity growth of petrochemical products, in particular main active ingredients for hand sanitizer such as alcohol and glycerol as well as for facemask, face shield, hand glove and protective clothes such as polyurethane, polypropylene, plastic, polyester and polyvinyl.

In spite of high demand of PPE, protective textiles and pharmaceutical products, however these chemical industries must not adversely affect the environment for future generations known by its sustainability for economics, environment and social aspects. To support this environmental concern of such industry, thus there is a need to implement the green concept. One of green concept for chemical manufactures is implementing the green supply chain management (GSCM) and green marketing mix (GMM)

GSCM is the latest development from supply chain management. The main target of GSCM is to degrade the endanger level from hazardous chemical, emissions, energy and solid waste along supply chain. GSCM involves the integration of environmental considerations into all stages of supply chain management activities, including green materials selection and packaging 
product design with consideration on environmental impact as well as clean disposal as the end of life management for products. Thus by enacting GSCM principles, it will generate additional on cost savings and prevent the natural resources from excess pollution, damage, and or wastefulness, by simultaneously (Lamb et al., 2013).

GSCM plays the main role for the chemical industry to reduce the environmental impacts to the business, which could reduce the business cost incurred to the business. Moreover, through implementation of GSCM, it would generate additional profit to the firm and increased service levels - and costs by reducing operating expenditure subject to environment problems minimization which affect the firm economic performance toward firm sustainability.

As GSCM aims to achieve improvements of business performance in economic therefore the adoption of green practices is also applied in the marketing activities. Currently, the marketing activities has start to promote green innovation concept by creating and deploying marketing programs that are relatively "greener" than their previous marketing undertakings. Indeed, the $\mathrm{B} 2 \mathrm{~B}$ sector tend to be more than in consumer marketing as there is a growing green market.

Green marketing mix (GMM), as part of marketing strategy will enable a firm to serve their target market in order to achieve organizational goals without harming the natural environment (Al-Salaymeh, 2013). GMM directly has a positive effect on sustainability economic performance and also has already started to be run within petrochemical industry in Indonesia (Farradia, et.al., 2019).

Based on the phenomenon of covid-19 prevention, governments, firms and individual consumers are more selective in purchasing basic products and materials unexpectedly and force to confront the fragility of the modern supply chain. Unfortunately, Banten Province in Indonesia as the major location for both chemical and petrochemical industry still needs to improve the environment performance because there are many chemical manufacturers still not implement the green industry management concept. Therefore, there is a need to study on the extent of GSCM and GMM practice toward firm sustainability in particular economic performance during the new norm era. 


\section{Literature Review}

\subsection{Personal Protective Equipment (PPE) and Hand Sanitizer}

Personal protective equipment (PPE) is designed to protect the wearer's body from injury or infection. The hazards addressed by protective equipment include physical, electrical, heat, chemicals, biohazards, and airborne particulate matter. During COVID-19, PPE is a compulsory for all people in particular for those who serve in hospital services. There are several types of PPE to prevent infectious materials during the COVID-19 crisis such as surgical masks, face shields, N95 respirators as well as disposable gloves and safety glasses.

Disposable medical glove's raw material such as vinyl, latex or nitrile is used to keep healthcare workers and patients from the spread of illness, whilst disposable coveralls which made from polypropylene is able to prevent form any contamination like virus. Other PPE used to prevent COVID-19 is N95 respirator masks which made from a flexible non-woven polypropylene. The raw material of disposable surgical masks is polypropylene, a thermoplastic polymer used in textile fibers. In addition, polystyrene, polycarbonate, polyethylene and polyester are also such raw material of disposable surgical masks. The face shield's visor raw material includes polycarbonate, propionate, acetate, polyvinyl chloride and polyethylene terephthalate glycol (PETG), whilst safety glasses and goggles is made by Chlorine.

Hand sanitization that contain alcohol in order to kill the germs present on the skin, works immediately and effectively in order to kill bacteria and most viruses. Hand disinfectant products can be chosen either anti-microbial soaps or alcohol-based hand sanitizers. The alcohol - based hand sanitizer is known as the most effective products due to its $62 \%-95 \%$ of alcohol formulation which able denaturing the proteins of microbes and inactivating viruses (Dixit et al., 2014; Kramer et al, 2006).

\subsection{New Norm Era of Covid-19}

Covid-19 reveals the criticality of the role of supply chain management in an organization. The COVID-19 crisis should reinforce the commitment that the government has made to climate actions by investing in green and sustainable projects and driving transformation in the Indonesian industries. Hence, the green stimulus is one of key recovery effort to not only bounce back the 
economy but also fight against the Corona virus pandemic in a country as well as be expected to create better air quality which minimize possibility of respiratory diseases on people communities.

The COVID-19 crisis should reinforce the commitment that the government has made to climate actions by investing in green and sustainable projects and driving transformation in the Indonesian industries. The adopting a new normal through shift to a green economy which indicates the urgency of shifting to a low-carbon economy in the post Covid-19 World .

On the other side, in the new normal era, there are some phenomenon on uncertainty, value priorities which one of the priority is long term sustainability and cash shortage matter. In order to recover the global lockdown of COVID19 global pandemic, it is a need to adopt green technologies as our 'new normal' for sustainable development, in particular for manufacturing industries as the major contributors to global climate change, environmental pollution and resource depletion. This can be the first step towards a global systematic change post COVID-19. Green supply chain management then is recommended during this new norm era.

\subsection{Green Supply Chain Management (GSCM)}

The modern humanity, governments, and business organizations put more focus on Sustainability and environmental in order to promote organizational sustainability, specifically for the emerging economies (Hsu et al., 2013; FabbeCostes et al., 2014; Tseng et al., 2015). Earlier studies, Dubey et al. (2015) and Zhu et al. (2012) have suggested that the regulatory bodies have forced the industries to improve adoption of green supply chain management (GSCM)

GSCM activities such as product design, material sourcing and selection, manufacturing processes up to finish good delivery and end-of-life management is an integration concept between environmental issues and supply chain management. The adoption of green technologies in the development of these industries will work as a propelling force in realizing sustainable development. Application and installation of energy and water-efficient system, construction efficient products like green-create technology will support energy generation, waste management and green construction. To have totally committed to sustainability it is important to bring green innovation to have an eco-friendly, cleaner and greener future.

GSCM covers both implementing and monitoring of the general environmental management programs in order to more creating or controlling practices implemented through various Rs (Reduce, re-use, rework, refurbish, 
reclaim, recycle, remanufacture, reverse logistics.) towards attaining a GSCM waste minimization is being considered as an important strategy.

GSCM practice objective is to reduce ecological risks of business processes at the minimum level without scarifying cost, quality, reliability, and energy. As most firms are very concern on environmental footprint, hence GSCM might has an opportunity to attract resources from socially concerned investors. Generally, eco-friendly practice in the firm behavior is closely related to significant stock price increases, whereas eco-harmful practice in the firm has an impact of their stock price decreasing (Flammer, 2013). Chin et al. (2015) found that the practice of green product and process design were the best predictor of sustainability performance because environmental collaboration, internal environmental practices, green product, and process design significantly had positive relationships with sustainability performance.

The resource-based view (RBV) is one of the most-adopted theoretical lenses in analyzing supply chain management (Carter et al., 2014). The resource-based view (RBV) emphasizes the firm's resources as the fundamental determinants of competitive advantage and performance. In 1995, Hart (1995) extended the RBV by adding natural environment as also the important source of resources and capabilities, creating the natural resource based value (NRBV). This NRBV has often been used to study green practices in the supply chain (Vachon \& Klassen, 2008). Thus, GSCM practices are considered capabilities developed from a given set of firm resources (Golicic \& Smith, 2013).

\subsection{Green Marketing Mix}

Green marketing mix, as one of the marketing mix strategy allows a firm to serve their customers without harming the natural environment (Al-Salaymeh, 2013). There are four categories of green marketing mix namely: green product, green price, green place and green promotion have a positive and significant relationship with purchase intention (Mahmoud, et al 2017). Hasan \& Ali . (2017) study results of modelling the relationship between green marketing strategies and performance outcomes for business sustainability at organizational performance among the ISO 14001 certified firms in Malaysia, also find that green product, green price, green promotion, green distribution, strategic competency, and marketing resources positively affects organizational performance.

Further study by Rahmawati et al. (2014) found that GMM has the important role to mediate the effect of environment option on firm competitive advantage. Prior study by Green (2012) concluded that marketing performance 
could contribute to financial performance within supply chain management. In addition, Zampese et al. (2016) found that green marketing has a mediator role between GSCM and organizational performance.

\subsection{Firm Economic Sustainability trough GSCM and GMM}

Most companies do various effort in order to reduce operational expenses and to serve the customers better toward firm sustainability in terms of economic performance. On the other side, an improvement of supply chain management is also one of the effort in order to win the competitive market of the day (Jain et al., 2010). One of this improvement is also by adding green concept to the supply chain management to promote green business process to the customers. In addition, Chin et al. (2015) found that environmental collaboration, internal environmental practices, green product, and process design have significant positive relationships with sustainability performance.

Relying on the RBV theory, the adoption of Internal and External GSCM practices is to extend the firm sustainability in particular economic performance. By combining with the marketing theory, then the effect of supply chain performance on sustainable economic performance is indirect through marketing performance (Green, 2012

\section{Methodology}

A research framework is proposed to investigate the relationship between internal and external GSCM and sustainable economic performance through the presence of GMM as mediator. The overall theoretical framework then can be illustrated in figure 1 as follow: 


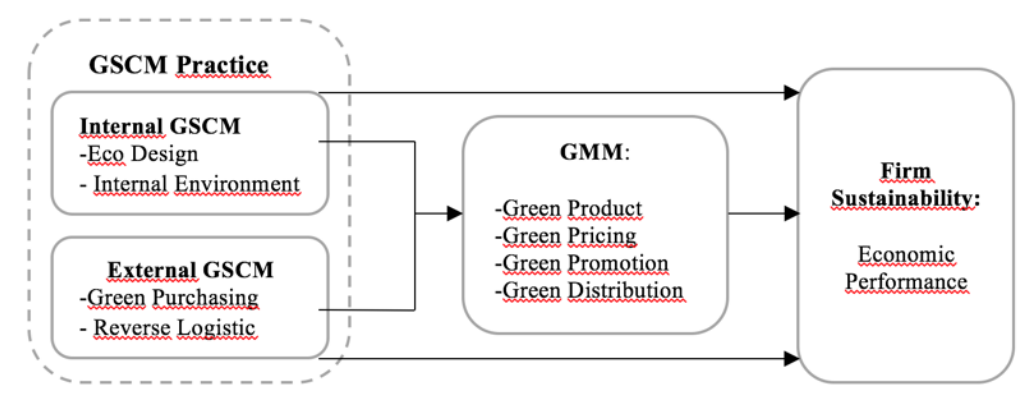

Fig 1: Theoretical framework

Based on the above framework, internal and external GSCM are independent variables used in this study. The Internal GSCM dimension are eco design which explain the green approach for both product and packaging being used and internal environment which explain green enforcement within the firm. On the other side, the external GSCM dimension are green purchasing which explore how firm select their supplier with green consideration and reverse logistics to express how firm can respond their customers subject to product return in green approach efficiently.

Dependent variable of this study is focus on economic performance as part of sustainability dimension. The GMM which will be tested for the mediator role is consist of four indicators green product, green pricing, green promotion and green distribution. As the object of this study is B2B, thus green distribution indicator is used to replace green place. Therefore, some hypotheses tested are:

$\mathrm{H}_{1}$ : Internal GSCM has positive effect on sustainability economic performance.

$\mathrm{H}_{2}$ : External GSCM has positive effect on sustainability economic performance

$\mathrm{H}_{3}$ : Internal GSCM has positive effect on GMM

$\mathrm{H}_{4}$ : External GSCM has positive effect on GMM

$\mathrm{H}_{5}$ : GMM has positive effect on sustainability economic performance.

$\mathrm{H}_{6}$ : GMM mediate external GSCM with sustainability economic performance. 
$\mathrm{H}_{7}$ : GMM mediate internal GSCM with sustainability economic performance.

The unit of analysis of the study is chemical industry, located in Banten province of Indonesia. According to Banten statistics bureau (2019), there were 241 chemical companies consist of medium up to large scale. The total sample is calculated based on Slovin's formula based on 90\% confidence level, as follow:

$$
\mathrm{n}=\frac{\mathrm{N}}{\mathrm{-}-\mathrm{Ne}^{2}}
$$

Where: $\quad \mathrm{n}=\#$ of sample size

$\mathrm{N}=$ total population

$\mathrm{e}=$ confidence level

As number of total population was 241 with $90 \%$ of confidence level therefore the target of sample based on slovin formula was 70 manufacturers. The respond from the targeted respondents was 58 manufacturers or $83 \%$ respond.

Two types of software were used for data analysis namely SPSS and SmartPLS. SmartPLS 3 was used to test the hypotheses by means of Structural Equation Model (SEM) from Partial Least Square (PLS). The construct model as illustrated in fig 2 below indicates a higher order construct model, therefore the model analysis is run through two stage least square approach.

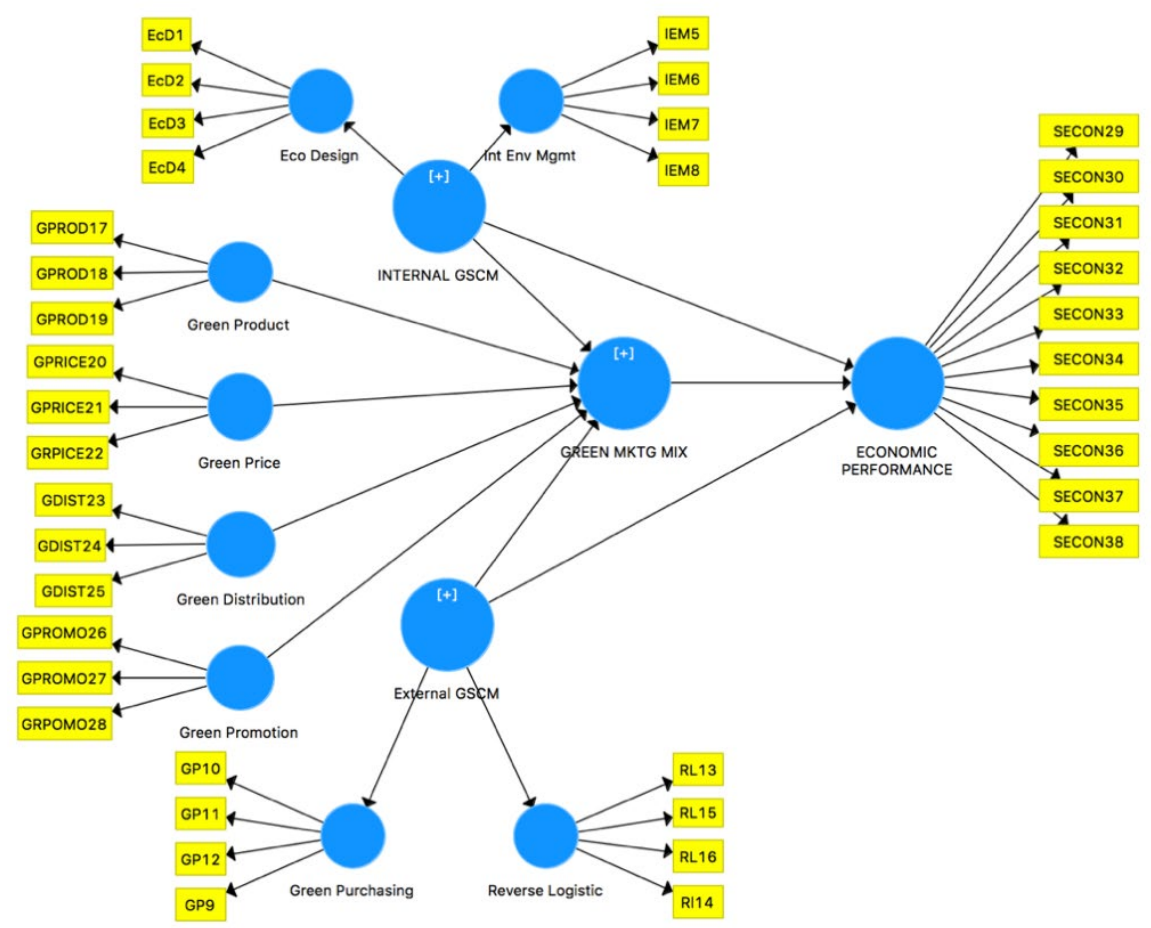


Fig 2: Economic Sustainability of GSCM and GMM model construct

\section{Result and Discussion}

\subsection{Result}

Based on the SPSS data screening, using mahalanobis tools, there was not outliers numbers. This result indicated the data was in well distribution. The model analysis done by smart pls 3 or construct was indicated that reliability of reflective construct for both first order and higher order construct full fill the threshold number above 0.7 for the loading factor, above 0.5 for the AVE and above 0.7 for the composite reliability. The all values of HTMT were also below 0.9 , thus it can be stated that there is no lack of discriminant validity (Henseler et al. ,2015; Hair et al ,2016). In addition, at both first and second order, it was indicated that there was no discriminant validity problem in this study because none of cross-loadings exceed their indicators' outer loadings. In addition, data analysis was also indicated there was no multicollinearity problem as indicated by the VIF value below 5 . Therefore, the model could be further run for the hypotheses testing. Final analysis to test the hypotheses are based on the structural model construct illustrated in figure 3 below.

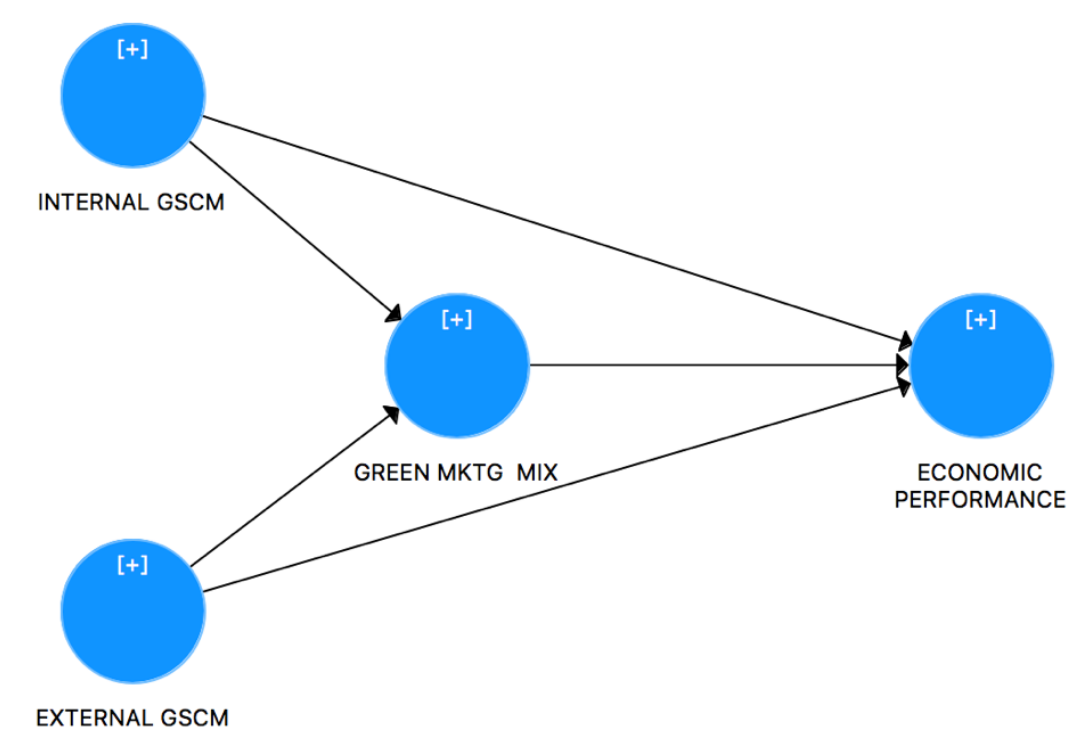

Fig 3: Economic Sustainability of GSCM and GMM - Structural Model 
The hypotheses result based on the structural model is tested based on some indicator thresholds presented in the table 1 below:

Table 1: Hypothesis testing

\begin{tabular}{|c|c|c|c|c|c|c|c|c|c|c|}
\hline $\begin{array}{l}\text { Hypo } \\
\text { Thesi } \\
\text { s }\end{array}$ & $\begin{array}{l}\text { Relation } \\
\text { Ship }\end{array}$ & $\begin{array}{l}\text { Std } \\
\text { Beta }\end{array}$ & $\begin{array}{c}\text { Std } \\
\text { Error }\end{array}$ & $\begin{array}{c}\mathrm{t}- \\
\text { value }\end{array}$ & $\underset{\text { value }}{\mathbf{p}-}$ & $\begin{array}{l}\text { Deci } \\
\text { sion }\end{array}$ & $\left(\mathbf{R}^{2}\right)$ & $\left(f^{2}\right)$ & $\left(Q^{2}\right)$ & $\left(q^{2}\right)$ \\
\hline $\mathbf{H}_{1}$ & $\begin{array}{l}\text { INTERNAL GSCM } \\
\rightarrow \text { SUSTAINABLE } \\
\text { ECONOMIC } \\
\text { PERFORMAN } \\
\text { CE }\end{array}$ & 0.113 & 0.113 & 1.004 & 0.158 & $\begin{array}{l}\text { Not } \\
\text { Suppor } \\
\text { ted }\end{array}$ & 0.587 & 0.016 & 0.250 & 0.001 \\
\hline $\mathbf{H}_{2}$ & $\begin{array}{l}\text { EXTERNAL GSCM } \\
\rightarrow \text { SUSTAINABLE } \\
\text { ECONOMIC } \\
\text { PERFORMAN } \\
\text { CE }\end{array}$ & 0.001 & 0.128 & 0.008 & 0.497 & $\begin{array}{l}\text { Not } \\
\text { Suppor } \\
\text { ted }\end{array}$ & 0.587 & 0.000 & 0.250 & 0.002 \\
\hline $\mathrm{H}_{3}$ & $\begin{array}{l}\text { INTERNAL GSCM } \\
\rightarrow \text { GREEN } \\
\text { MARKETING MIX }\end{array}$ & 0.354 & 0.108 & 3.280 & 0.001 & $\begin{array}{c}\text { Suppor } \\
\text { ted }\end{array}$ & 0.487 & 0.158 & 0.255 & 0.063 \\
\hline $\mathbf{H}_{4}$ & $\begin{array}{l}\text { EXTERNAL GSCM } \\
\rightarrow \text { GREEN } \\
\text { MARKETING MIX }\end{array}$ & 0.427 & 0.114 & 3.728 & 0.000 & $\begin{array}{c}\text { Suppor } \\
\text { ted }\end{array}$ & 0.487 & 0.229 & 0.255 & 0.078 \\
\hline $\mathrm{H}_{5}$ & $\begin{array}{l}\text { GREEN } \\
\text { MARKETING MIX } \\
\rightarrow \text { SUSTAINABLE } \\
\text { ECONOMIC } \\
\text { PERFORMAN } \\
\text { CE }\end{array}$ & 0.450 & 0.138 & 3.262 & 0.001 & $\begin{array}{c}\text { Suppor } \\
\text { ted }\end{array}$ & 0.587 & 0.213 & 0.250 & 0.042 \\
\hline
\end{tabular}

The Hypothesis $\mathrm{H}^{1}$ and $\mathrm{H}^{2}$ were rejected as indicated by the value of $\mathrm{p}$ - value which above 0.05 and $t$ value below 1.96 . Whilst the other hypotheses $\mathrm{H}^{3}, \mathrm{H}^{4}$ and $\mathrm{H}^{5}$ were accepted subject to the $\mathrm{p}$ and $\mathrm{t}$ value threshold.

The mediator hypotheses results were presented in the table 2, explain that the mediator was occurred. Means the hypotheses was accepted.

Table 2 : Hypothesis testing on mediation 


\begin{tabular}{|c|c|c|c|c|c|c|c|c|}
\hline \multirow{2}{*}{ Hypothesis } & \multirow{2}{*}{ Relationship } & \multirow{2}{*}{$\begin{array}{l}\text { Std. } \\
\text { Beta }\end{array}$} & \multirow{2}{*}{$\begin{array}{l}\text { Std. } \\
\text { Error }\end{array}$} & \multirow{2}{*}{$\begin{array}{c}\text { T } \\
\text { Statistics } \\
(\mid \mathbf{O} / \mathrm{STD} \\
\text { EV|) }\end{array}$} & \multirow{2}{*}{$\begin{array}{c}\mathbf{P} \\
\text { Value }\end{array}$} & \multicolumn{2}{|c|}{$\begin{array}{c}\text { Confidence } \\
\text { Interval (BC) }\end{array}$} & \multirow{2}{*}{ Decision } \\
\hline & & & & & & $\begin{array}{l}2.5 \% \\
\text { (LL) }\end{array}$ & $\begin{array}{c}97.5 \% \\
\text { (UL) }\end{array}$ & \\
\hline $\mathrm{H}_{6}$ & $\begin{array}{l}\text { EXTERNAL } \\
\text { GSCM -> } \\
\text { GREEN } \\
\text { MARKETIN } \\
\text { G MIX -> } \\
\text { ECONOMIC } \\
\text { PERFORMA } \\
\text { NCE } \\
\end{array}$ & 0.192 & 0.085 & 2.265 & 0.024 & 0.050 & 0.359 & Supported \\
\hline $\mathrm{H}_{7}$ & $\begin{array}{l}\text { INTERNAL } \\
\text { GSCM -> } \\
\text { GREEN } \\
\text { MARKETIN } \\
\text { G MIX -> } \\
\text { ECONOMIC } \\
\text { PERFORMA } \\
\text { NCE }\end{array}$ & 0.159 & 0.069 & 2.304 & 0.022 & 0.040 & 0.308 & Supported \\
\hline
\end{tabular}

Both mediator hypotheses $\mathrm{H}^{6}$ and $\mathrm{H}^{7}$ value of $\mathrm{t}$ and $\mathrm{p}$ shows that these value fulfill the requirement above 1.97 and below 0.5 respectively. In addition there is no zero value between the low level (LL) and upper level (UL) of the confidence interval value supported the mediator hypotheses.

\subsection{Discussion}

Based on the hypotheses results it explained that the Implementation of both internal and external GSCM practices become the basis of green marketing strategy to the customer. In addition to this, high customer satisfaction based on 'green needs' fulfillment will generate customer loyalty to the firm. On the other side the internal GSCM innovate the development of green product from its design, raw materials up to the packaging, whilst IEM through high enforcement of green system management within overall process production. Whilst the external effort such implementing green purchasing and reverse logistics.

Sustainable economic performance could be achieved by implement both internal and external GSCM integrated with GMM. The profit gain is generated from both revenue and cost saving due to the effect of GSCM practices which 
might reduce any fee of waste treatment, cost of energy consumption and environment accidents.

\section{Conclusion and Recommendation}

In conclusion it can be summarized that GSCM has a positive indirect effect through GMM on economic sustainability. On the other side GMM has a positive direct effect on economic sustainability. The recommended model proposed then is follow:

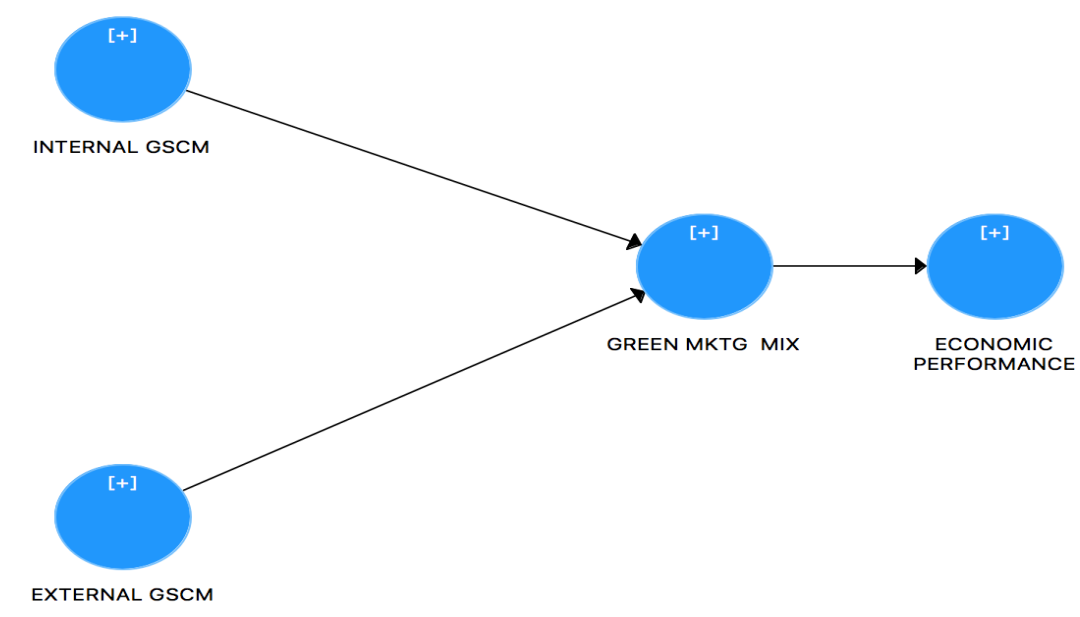

Fig 4. Recommended Model

Acknowledgments. Thank you for the support from the Faculty of Economics Universitas Pakuan, Bogor - Indonesia. 


\section{References}

[1]. Accenture. Navigating the human and business impact of COVID-19 on the chemical $\quad$ industry. $2020 . \quad$ Available at https://www.accenture.com/usen/insights/chemicals/coronavirus-buildingresilience-amid-disruption-chemical-industry (accessed in July 2020).

[2]. Al-Salaymeh M. (2013). The Application of the Concept of Green Marketing in the Productive Companies from the Perspective of Workers. Interdisciplinary journal of contemporary research in business. 4(12), 634- 641.

[3]. Banten Statistic Bureau (2019). Banten Province in Figures. Publised by BPSStatistics of Banten Province

[4]. Carter, C. R., L. M. Ellram, L. Kaufmann, C. W. Autry, X. Zhao, \& Callarman, T. E. (2014). Looking Back and Moving Forward: 50 years of the Journal of Supply Chain Management. Journal of Supply Chain Management. 50 (1): 1-7

[5]. Chin, T., Tat, H. \& Sulaiman, Z. (2015). Green Supply Chain Management, Environmental Collaboration and Sustainability performance. Procedia CIRP, $26,695-699$

[6]. Coatingsworld. Impact on global chemical industry due to COVID-19 pandemic. 2020. Available at https://www.coatingsworld.com/contentmicrosite/cw covid-19/2020-04-15/impact-on-global-chemical-industry-dueto-covid-19-pandemic (acessed in July 2020).

[7]. Dixit, A., Pandey, P., Mahajan, R., \& Dhasmana, D. C. (2014). Alcohol based hand sanitizers: Assurance and apprehensions revisited. Res. J. Pharm. Biol. Chem. Sci. 5, 558-563.

[8]. Dubey, R., Gunasekaran, A, \& Ali, S. (2015). Exploring the Relationship between Leadership, Operational Practices, Institutional Pressures and Environmental Performance: A Framework for Green Supply Chain. International Journal of Production Economics, Vol. 160, Part A, 120 -132.

[9]. Fabbe-Costes, N., Roussat, C., Taylor, M. \& Taylor, A. (2014). Sustainable Supply Chains: A Framework for Environmental Scanning Practices. International Journal of Operations and Production Management, Vol. 34 No 5, 664-694.

[10]. Farradia, Y., Bon, A. T., \& Rully, T. (2019). Green Marketing Mix Role Toward Sustainability Performance Petrochemical Industry in Indonesia. Industrial Engineering and Operations Management Proceeding. p. 3640 - 3650. 9th IEOM Conference 2019). Bangkok, March 5-7, 2019 
[11]. Flammer, G. (2013). Corporate Social Responsibility and Shareholder Reaction: The Environmental Awareness of Investors. Academy of Management Journal, 56, 758-781.

[12]. Fornell, C., \& Larcker, D. F. (1981). Evaluating Structural Equation Models with Unobservable Variables and Measurement Error. Journal of Marketing Research, (18:1), 39-50.

[13]. Golicic, S. L., \& Smith, C. D. (2013). A Meta-Analysis of Environmentally Sustainable Supply Chain The Supply Chain Position Paradox. January 2017 Volume 53, Number 1 management practices and firm performance. Journal of Supply Chain

[14]. Green, Jr K. W., Whitten, D., \& Inman, R. A. (2012). Aligning marketing strategies throughout the supply chain to enhance performance. USA: Industrial Marketing Management, 41(6), 1008-1018.

[15]. Hair, J. F., Hult, G. T. M., Ringle, C., \& Sarstedt, M. (2016). A Primer on Partial Least Squares Structural Equation Modeling (PLS-SEM). 2nd Edition. New York: SAGE Publications.

[16]. Hart, S. L. (1995) A natural-resource-based view of the firm. The Academy of Management Review, Vol. 20 (4), 986-1014.

[17]. Hasan, Z \& Ali, N. A. (2017). Modelling the Relationship Between Green Marketing Strategies and Performance Outcomes for Business Sustainability. Global Conference on Business and Economics Research (GCBER). 14-15 August 2017, Universiti Putra Malaysia, Malaysia Available online at August 14-15, UPM, Malaysia

[18]. Henseler, J., Ringle, C.M. \& Sarstedt, M. (2015), A new criterion for assessing discriminant validity in variance-based structural equation modeling, Journal of the Academy of Marketing Science, Vol. 43 No. 1, 115-135.

[19]. Hsu, C., Tan, K. C., Zailani, S. H. M., \& Jayaraman, V. (2013). Supply Chain Drivers that Foster the Development of Green Initiatives in An Emerging Economy, International Journal of Operations \& Production Management, Vol. 33 No. 6, 656-688

[20]. Jain, J. K., Dangayach, G. S., \& Agarwal, G. (2011). Evidence of Supply Chain Management in Indian manufacturing firms: A survey. International Journal of Management Science and Engineering Management, 6(3): 198-209

[21]. Kramer, A., Galabov, A. S., Sattar, S. A., Döhner, L., Pivert, A., Payan, C., Wolff, M. H., Yilmaz, A., \& Steinmann, J. (2006). Virucidal activity of a new hand disinfectant with reduced ethanol content: Comparison with other alcoholbased formulations. J. Hosp. Infect., 62, 98-106. [CrossRef] 
[22]. Lamb, C.W., Hair, J.F.Jr., \& McDaniel, C. (2013). Marketing. Mike Schenk publisher. South Western. Chengage Learning. pp. 226.

[23]. Lazonby, J \& Waddington, D. The Essential Chemical Industry -online. (2020). Available at https://www.essentialchemicalindustry.org/the-chemicalindustry/the-chemical-industry.html (acessed in July 2020)

[24]. Mahmoud, T. O., Ibrahim, S. B., Ali, A. H., \& Bleady, A., (2017). The Influence of Green Marketing Mix on Purchase Intention: The Mediation Role of Environmental Knowledge. International Journal of Scientific \& Engineering Research, Volume 8, Issue 9.

[25]. Rahmawati, R, Hadiwidjojo, D, \& Noermijati, S. (2014). Green Marketing Mix As Strategy to Improve Competitive Advantage in Real Estate Developer Companies. International Journal Of Business And Management Invention, Vol 3 Issue 11, 06-12

[26]. Rais, A. The Impact on China Chemical Industry due to the Covid-19 Pandemic. China: Market Insight. (2020). Available at https://www.processworldwide.com/the-impact-on-china-chemical-industry-due-to-the-covid-19pandemic-report-released-a-938517/. (accessed in July 2020).

[27]. Strategy\&pwc.com. Preparing the chemicals industry for the day after the covid 19 pandemic. Discussion document pwc. (2020). Available at https://www.strategyand.pwc.com/de/de/implications-of-covid19/consequences-for-the- chemicals-industry.html

[28]. The Jakarta Post (2020). PPE production soars but quality distribution issues remain. Available at https://www.thejakartapost.com/news/2020/06/10/ppeproduction-soars-but-quality-distribution-issues-remain.html. (accessed in June 2020)

[29]. Tseng, M. L., Lim, K. M. \& Wong, W. P. (2015), Sustainable Supply Chain Management: A Closed - Loop Network Approach. Industrial Management and Data System, Vol. 115 No 3, 436-461.

[30]. Vachon, S. \& Klassen, R.D. (2008). Environmental management and manufacturing performance: The role of collaboration in the supply chain. International Journal of Production Economics, Vol. 111 (2), 299- 315.

[31]. Zampese, E. R. D. S., Moori, R. G., \& Caldeira, A. (2016). Green marketing as a mediator between supply chain management and organizational performance. Ram, Rev. Adm. Mackenzie, 17 (3), 183-211.

[32]. Zhu, Q., Sarkis, J, \& Lai, K. (2012). Examining the Effects of Green Supply Chain Management Practices and Their Mediations on Performance Improvements. International Journal of Production Research, 50 (50), 1377 1394. 